\title{
Influence of probiotic on serum biochemical profile, growth performance and immunostatus in broiler chickens
}

\author{
M. A. Abonorag ${ }^{1 *}$, Elham A. Mobarez ${ }^{1}$, Y. A. Elkatan ${ }^{1}$, Sahar A. Galal $^{1}$, Nahla \\ Sh. Kotb ${ }^{2}$ \\ ${ }^{1}$ Animal Health Reaserch Institute and ${ }^{2}$ National Organization for drug Control and research
}

\begin{abstract}
A total of 90 one-day-old male broiler chicks were fed on balanced ration for 15 days and then divided into 3 equal groups. Control group fed ration probiotic free, group 2 and 3 fed ration supplemented with probiotic at concentration levels 0.5 and $1.0 \mathrm{~g} / \mathrm{kg}$ ration respectively for 4 weeks.It was found that probiotic improve body weight gain and feed conversion ratio. Relative organs weights were not altered in groups of birds fed ration mixed with probiotic. Serum values of biochemical parameter (AST, ALT, ALP, total protein, A/G ratio, Ph) were not significantly changed in comparison to control group. Probiotic enhance the immune response of broiler chickens in a dose dependent relation as documented by increasing the serumNDHI antibody geometric mean titres to ND vaccine, phagocyte percentage and phagocytic index of peripheral blood monocyte of broiler chickens. We concluded that probiotic composed of 3 strains of bacteria (Pediococcus acidilactici, Pediococaoccus pentosaceus and Bacillus Amylolique-faciens) in addition to 2 strains of yeast( Pichia farinose and Dekera anomala) enhance body weight gain, feed conversion, growth performance and Newcastle disease antibody titres in broiler chickens. Moreover, probiotic was safe as proved by serum biochemical profile and relative organ weight of male broiler chickens.
\end{abstract}

Antimicrobials have been supplemented to poltry feed for more than 50 years to enhance growth performance and to prevent diseases in poultry.However, in recent years great concern has been arisen about the addition of antibiotics at sub-therapeutic level to poultry feed. Due to emergence of multiple drug resistant bacteria (Wray and Davies, 2000) antibiotics as a feed additive was recommended to be replaced by alternatives such as probiotic.

Probiotic are live non pathogenic microorganism that when administered in adequate amount exert beneficial to host health and immune system, through out improvement in intestinal microbial equilibrium (Fuller, 1989; Reid et al., 2003; Gunal, et al., 2006; Vinderola et al., 2006). Therefore, they are called friendly bacteria. They cooperatively maintain a delicate balance between the gastro-intestinal tract and immune system, when this balance is disrupted, diseases and inflammation results. Inflammation and over stimulation of the immune system by pathogenic bacteria are competitively inhibited by mucosal adherence of normal beneficial microflora (Wysocka, 2001) however, the role of different types of probiotic on health performance, serum biochemical changes and immunostatus of male broiler chicks still not fully clear.

Therefore, this study purposed the evaluation of the effect of a new probiotic (3 strains of bacteria and 2 strains of yeast) in serum biochemical profile, performance (body weight gain and feed conversation), and immunostatus of broiler chickens.

\section{Materials and methods}

Probiotic. Probiotic (BIOWISH) ${ }^{\mathrm{R}}$ was obtained from OCTA Egypt Company in the form of feed additives powder.It was composed of 3 strains of bacteria (Pediococcus acidilactici, Pediococaoccus pentosaceus and Bacillus Amylolique-faciens) in addition to 2 strains of yeast (Pichia farinose and Dekera anomala and vehicles). It was added to the ration in two concentration levels 0.5 or $1 \mathrm{~g} / \mathrm{kg}$ ration for 4 successive weeks.

Experimental design. A total of 90 one-day-old male Hubbard broiler chickens were fed on balanced ration and water ad libitum for 15 days, then divided randomly into 3 equal groups of 30 birds each. Group 1. fed ration probiotic free (control group). Group 2. fed ration supplemented with probiotic 0.5 gram $/ \mathrm{kg}$ ration. Group 3. fed ration supplemented with probiotic $1 \mathrm{~g} / \mathrm{kg}$ ration.

Vaccination. Broilers were vaccinated through

* Corresponding author. Tel.: +20 017 9403957;

E-mail address: abonoragmam@yahoo.com.

(Mostafa Abonorag). 
drinking water by La Sota strain at $17^{\text {th }}$ day then repeated every 10 days intervals.

Ration. A basal ration was formulated and considered as control according to recommendation of NRC (1994) for starter (0-21 days, crude protein $21 \%$ ) and grower (22-42 days, crude protein $18.5 \%$ ).

All birds were reared on floor pens for the end of the experiment (42 days).

Body weight gain and feed conversion ratio were recorded weekly. Birds were slaughtered at the end of the experiment for weighing of carcasses, feather and skin, liver, gizzard, heart and spleen.

\section{Blood sampling. Blood samples were collected} for:

Biochemical studies. At $42^{\text {nd }}$ days of the experimental period $5 \mathrm{ml}$ of blood/bird was collected from wing vein from birds in each group. Blood samples were centrifuged (at 3000 $\mathrm{x} \mathrm{rpm}$ for $10 \mathrm{~min}$ ) and serum was separated and stored at $-20^{\circ} \mathrm{C}$ until assayed for the following, using appropriate laboratory kits for AST, ALT and ALP (Tietz, 1999); total protein and albumin (Young, 1995). The serum globulin was calculated by subtracting serum albumin from serum total protein levels and $\mathrm{A} / \mathrm{G}$ ratio. Creatinine was determined according to Bartels, (1961) while, calcium and phosphorus was detected according to Tietz, (1995).

Immunological status studies. Blood samples were collected from all groups of birds every ten days post vaccination for serum separation to determined antibody against Newcastle diseases virus (NDV) vaccine by haemagglutination inhibition (HI). Hepranized blood samples were collected at $1^{\text {st }}$ day post the booster dose to determine the phagocytic activities.

Haemagglutination inhibition test (HI). The serum samples were utilized for HI test to find out the level of antibody titres developed against NDV vaccine in different groups of birds. The test was carried out according to King and seal, (1998).

Phagocytosis. Mononuclear phagocytic activity: Peripheral blood monocytes activity was carried out using Candidia albicans by seperation of peripheral blood mononuclear cells as described by Boyum, (1968). Mononuclear cell layer was collected, washed and resuspended in RPMI1640 supplemented with $10 \%$ foetal calf serum and viability was done after Hanks and Wallace, (1985).The test was performed according to procedure described by Chu and Dietert, (1989). Stastistical analysis. Data were an analyzed using the one-way ANOVA procedure according to Petrie and Watson, (1999) and t-test (Snedecor, 1969).

\section{Results and discussion}

The obtained result revealed that ration supplemented with probiotic at concentration 0.5 or $1 \mathrm{~g} / \mathrm{kg}$ ration improve body weight gain in comparison to control group of birds (Tables, 1, 2, Fig.1). Feed conversion rate was improved in group of chicks fed ration mixed with probiotic $0.5 \mathrm{~g} / \mathrm{kg}$ ration (2.5) than either birds fed $1 \mathrm{~g}$ probiotic $/ \mathrm{kg}$ ration or control group of birds fed ration free probiotic (3.3 and 3.4 respectively) (Table 3, Fig. 2). The improvement of body weight gain and feed conversion in group of birds fed ration supplemented with probiotic might be due to improved intestinal microbial balance, reduced pathogenic flora which accelerated food absorption (Swain et al., 1996). Probiotic may stimulate appetite and improve nutrition by the production of digestible enzymes, vitamins and detoxification of injurious compounds in the diet (Pelicano et al., 2003).

Our result substantiated the findings of Thitaram et al., (2005); Nayebpor et al. (2007); Ashayerizadeh et al. (2009) who reported that probiotics can improve the weight of birds. Moreover, adding probiotic to the ration was effective in improving the feed conversion ratio (Zulkifli et al., 2000; Cavit, 2004), Which is contrary to the report of Gunal et al., (2006); Willis et al., (2007); Yalcinkayal et al., (2008) who reported that using this additives shed in the broiler ration had no significant effects on body weight gain and feed conversion ratio after 42 days (the experimental period).

For safety evaluation of probiotic as a fed additive, it was found that relative organs weights of liver, gizzard, heart and spleen were within the normal weight without any significant changes as comparied with the control group of birds (Table, 4). This indicates that probiotic not affect organ weight in birds in group 2 or 3 . This finding was in agreement with Mohan et al., (1996); Islam et al., (2004) who found that supplementation of chicken with probiotics had no significant effect on relative organs weights. While the relative carcass weight of chicken groups fed ration mixed wih probiotic $(0.5 \mathrm{~g} / \mathrm{kg}$ ration) was increased significantly $(\mathrm{P}<0.01)$.

Regarding, the recorded serum biochemical parameter including total protein, albumin, ALT, AST, ALP, creatinine and phosphorus, there was no significant alteration by the probiotic addition to the ration of chickens (Table, 5). Similarly, 
Table (1): Body weight $(\mathrm{g})$ of male broiler chickens fed ration mixed with probiotic at different concentration levels $(0.0,0.5$ and $1 \mathrm{~g} / \mathrm{kg}$ balanced ration) (mean \pm S.E. $) \mathrm{n}=30$.

\begin{tabular}{lcccccc}
\hline \multirow{2}{*}{ Group } & Dose & \multicolumn{5}{c}{ Age/weeks } \\
\cline { 3 - 7 } & $(\mathbf{g} / \mathbf{k g}$ ration) & $\mathbf{2}^{\text {nd }}$ week & $\mathbf{3}^{\text {rd }}$ week & $\mathbf{4}^{\text {th }}$ week & $\mathbf{5}^{\text {th }}$ week & $\mathbf{6}^{\text {th }}$ week \\
\hline Control group & 0.0 & $333.8 \pm 7.03$ & $753 \pm 21.67$ & $1225.17 \pm 26.27$ & $1792.67 \pm 41.75$ & $1917.17 \pm 47.63$ \\
2nd group & 0.5 & $362.73 \pm 6.67^{* *}$ & $787.667 \pm 14.97$ & $1309.5 \pm 22.11^{*}$ & $1902.5 \pm 31.25^{*}$ & $2270 \pm 40.11^{* * *}$ \\
3rd group & 1 & $362.83 \pm 5.83^{* *}$ & $771.5 \pm 15.78$ & $1267.5 \pm 22.20$ & $1798 \pm 36.84$ & $2137 \pm 53.02^{* *}$ \\
\hline
\end{tabular}

Significant at $* \mathrm{P}<0.05 * * \mathrm{P}<0.01 * * * \mathrm{P}<0.001$

Table (2): Body weight gain of male broiler chickens fed ration mixed with probiotic at different concentration levels $(0.0,0.5$ and $1 \mathrm{~g} / \mathrm{kg}$ balanced ration) for 4 successive weeks (mean \pm S.E.) $\mathrm{n}=30$.

\begin{tabular}{lccccc}
\hline Group & Dose $(\mathbf{g} / \mathbf{k g}$ ration) & $\mathbf{3}^{\text {rd }}$ week & $\mathbf{4}^{\text {th }}$ week & $\mathbf{5}^{\text {th }}$ week & $\mathbf{6}^{\text {th }}$ week $^{\text {(n) }}$ \\
\hline Control group & 0.0 & $419.2 \pm 17.1$ & $472.17 \pm 9.61$ & $570.83 \pm 15.99$ & $251.72 \pm 10.22$ \\
$2^{\text {nd }}$ group & 0.5 & $424.93 \pm 11.62$ & $521.83 \pm 11.99 * *$ & $593.62 \pm 17.72$ & $387.14 \pm 14.38^{* * *}$ \\
$3^{\text {rd }}$ group & 1 & $408.67 \pm 11.84$ & $496.0 \pm 9.895$ & $528.1 \pm 17.51$ & $353.45 \pm 26.19^{* *}$ \\
\hline
\end{tabular}

Significant at $* * \mathrm{P}<0.01 \quad * * * \mathrm{P}<0.001$

Table (3): Mean of body weight gain, mean of ration consumed and mean of feed conversion ratio of male broiler chickens fed ration mixed with probiotic at different concentration levels $(0.0,0.5$ and $1 \mathrm{~g} / \mathrm{kg}$ ration ) for 4 successive weeks (Mean \pm S.E. ) $\mathrm{n}=30$.

\begin{tabular}{lcccc}
\hline Groups & $\begin{array}{c}\text { Dose } \\
(\mathbf{g} / \mathbf{k g} \text { ration) }\end{array}$ & $\begin{array}{c}\text { Mean of body } \\
\text { wt. gain }\end{array}$ & Feed conversion & $\begin{array}{c}\text { Mean of total ration } \\
\text { consumed (kg) }\end{array}$ \\
\hline Control group & 0.0 & $1604.24 \pm 53.41$ & 3.4 & 5416 \\
$2^{\text {nd }}$ group & 0.5 & $1947.83 \pm 68.87^{* * *}$ & 2.5 & 4833 \\
$3^{\text {rd }}$ group & 1 & $1697.41 \pm 80.76$ & 3.2 & 5416 \\
\hline
\end{tabular}

Significant at $* * * \mathrm{P}<0.001$.

Midilli et al., (2004) observed that feeding of probiotic did not affect the serum total protein in the treated groups of broilers. Also Rangasamy and Kaliappan, (2007) reported that the serum ALP, AST, ALT and total protein levels in probiotic broiler fed groups were not significantly differ from control group.

Globulin and $\mathrm{A} / \mathrm{G}$ ratio were increased significantly in group of birds fed ration mixed with probiotic $1 \mathrm{~g} / \mathrm{kg}$ ration. This may indicate that probiotic at this concentration enhance globulin formation which indicate higher defensive mechanism of the birds. These results were assured by immunological studies as it was reported that probiotics stimulate production of natural antibodies in chickens (Hamid et al., 2006). However, serum calcium concentration was decreased significantly $(p<0.01)$ in group of birds fed ration mixed with probiotic at $1 \mathrm{~g} \backslash \mathrm{kg}$ ration in comparison to control group but still within normal serum calcium levels of broiler (Table 5) without any adverse effect of hypocalcemia. This result was in agreement with Antunovic et al., (2005).They found that serum calcium level decreased significantly $(\mathrm{P}<0.01)$ in lamb fed ration mixed with probiotic for 35 days.

Geometric mean HI titres against NDV are shown in (Table 6). The HI titre against NDV were higher in groups 2 and 3 of broiler fed $0.5 \mathrm{~g}$ and $1 \mathrm{~g}$ probiotics/kg ration respectively, while the control group which fed basal diet (Group1) recorded the lower titre. The level of NDHI titre was increased continuously up to 30 days post vaccination in probiotics treated groups (2 and 3 ) as compared with the control one. Rangasamy and Kaliappan, (2007) indicating immunomodulatory effect of probiotics in broilers, and a higher HI titre against NDV in probiotic treated groups while, the control showed low titre, additionally Kabir et al., (2004) found that supplementation of probiotics significantly increased the antibody production in broilers. 


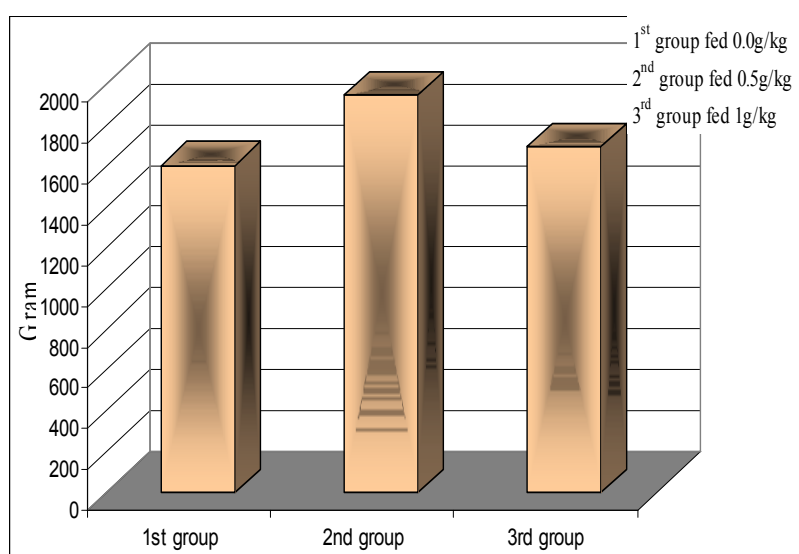

Fig. (1): Body weight gain for male broiler chicks fed ration mixed with probiotic at different concentration levels $(0.0,0.5$ and $1 \mathrm{~g} / \mathrm{kg}$ ration) for 4 successive weeks.

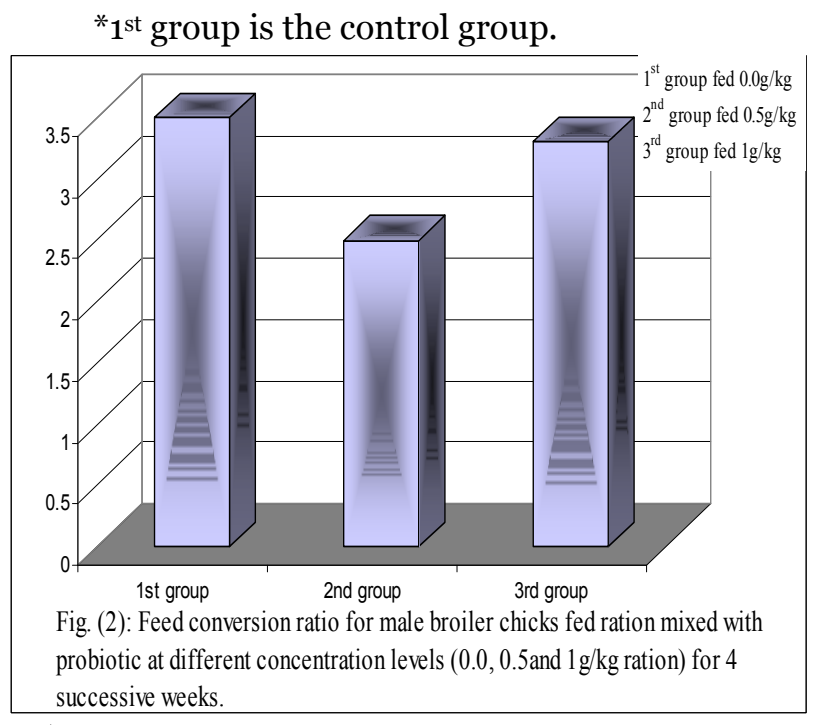

$* 1^{\text {st }}$ group is the control group

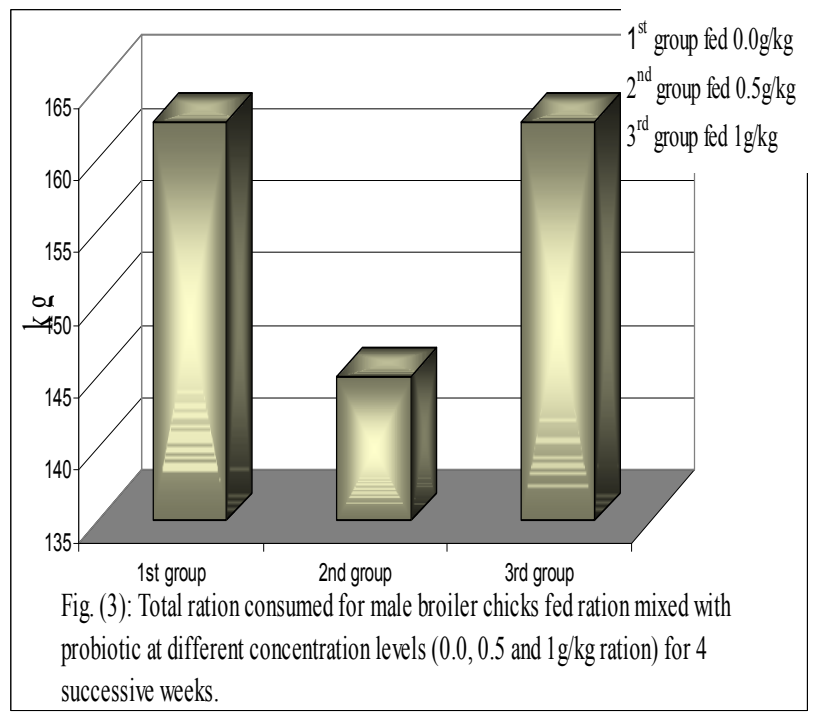

Referring to phagocytic activity of monocytes (Table 7), a significant increase was recorded in both phagocytic percentage and index in all treated group as compaired to control group. Probiotic bacteria contact as mucosal and systemic adjuvant, this induced an interaction of probiotic bacteria with the immune cells of payer's patches from the innate immune system, and therefore cytokines production is enhanced. These cytokines are the biological messengers of signals that activate the systemic immune response (Galdeano et al., 2007). Also, Schiffrin et al., (1997) stated that a bacterial signal could also act directly on epithelial cells or the intraepithelial lymphoid compartment of the proximal small intestine. This lymphoid population, on activation, can produce cytokines, such as interferon $\gamma$ and interleukin 2 (Ebert, 1989 and 1990). Cytokines released from these lymphoid populations may then act locally or alter the systemic reactivity of the host. It is tempting to speculate that for some probiotic activities such as immunomodulation. This may explain that probiotic confer immune adjuvant properties to the host when administered in appropriate dose. The ability of probiotics to prevent several pathological conditions was by stimulating the immune system to generate an immune response to be able to interact or send signals to immune cells associated with the gut (Isolauri et al., 2001).

In conclusion, dietary supplementation of probiotic for male broiler chickens significantly increased body weight gain, feed conversion ratio and improve immunostatus. Moreover, probiotic was safe as proved by serum biochemical profile and relative organ weight of male broiler chickens. In veterinary medicine probiotics may be effectively used to optimize digestive processes, stimulate growth and prevent diseases of the digestive tract.

\section{References}

Antunovic, Z.; Speranda, M.; Liker, B.; Soric, V.; Sercic; Domacinovic, M. and Sperada, T. (2005): Influence of feeding the probiotic PionEER PDFA Reg to growing lambson their performance and blood composition. Acta-Veterinaria-Beograd. 55(4).287-300.

Ashayerizadeh, A.; Dabiri, N.; Ashayerizadeh, O.; Mirzadeh, K. H.; Roshanfekr, H. and Mamooee, M. (2009): Effect of dietary antibiotic, probiotic and prebiotic as growth promoters on growth performance, carcass characteristics and hematological indices of broiler chickens. Pakistan Journal of Biological Sciences; 12(1): 52-57.

Bartels, H. (1961): A colorimetric methods for creatinine estimation. J. Clin. Acta.; 32, 81.

Boyum, A. (1968): Isolationof mononuclear cells and granuelocytes from human blood . Can. J. Clin. Invest., 21: 77-89.

Cavit. A. (2004): Effect of dietary probiotic supplementation on growth performance in the rock partridge ( Alectoris graeca ). Turk. J. Vet. Anim. Sci.; 28: 887-891. 


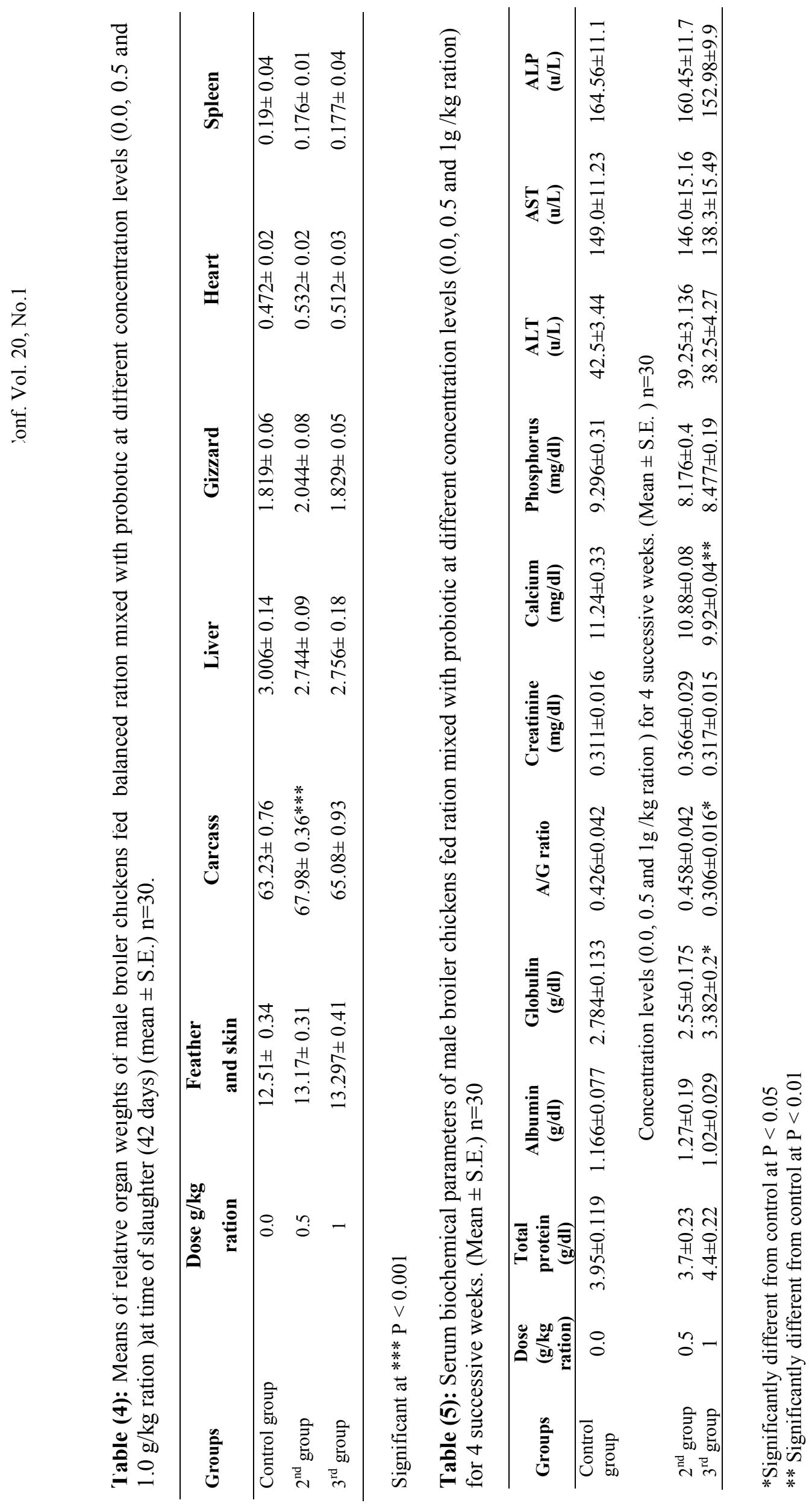

I.on coz i o 
Table (6): Serum antibody Geometric mean titres of ND vaccinated chickens by Haemagglutination inhibition (HI) test in male broiler chicks fed ration mixed with probiotic at different concentration levels $(0.0,0.5$ and $0.1 \mathrm{~g} / \mathrm{kg}$ ration $)$.

\begin{tabular}{lcccc}
\hline \multirow{2}{*}{ Groups } & $\begin{array}{c}\text { Dose } \\
(\mathbf{g} / \mathbf{k g} \text { ration })\end{array}$ & $\mathbf{1 0}$ days & $\mathbf{2 0}$ days & $\mathbf{3 0}$ days \\
\cline { 3 - 5 } & 0.0 & 49.324 & 89.808 & 123.286 \\
Control group & 0.5 & 54.975 & 93.845 & 155.965 \\
2nd group & 1 & 52.293 & 90.166 & 146.979 \\
3rd group & & &
\end{tabular}

Table (7): Avearage phagocytosis of peripheral blood monocyte of broiler chickens fed ration mixed with probiotic at different concentration levels $(0.0,0.5$ and $1.0 \mathrm{~g} / \mathrm{kg}$ ration $) .(\mathrm{m} \pm \mathrm{s} . \mathrm{e})$.

\begin{tabular}{lccc}
\hline \multirow{2}{*}{ Groups } & Dose & \multicolumn{2}{c}{ Parameter } \\
\cline { 3 - 4 } & $(\mathbf{g} / \mathbf{k g}$ ration) & Phagocytic percentage & Phagocytic percentage \\
\cline { 3 - 4 } & 0.0 & $54.00 \pm 0.577^{\mathrm{c}}$ & $54.00 \pm 0.577^{\mathrm{c}}$ \\
\hline Control group & 0.5 & $62.00 \pm 1.154^{\mathrm{a}}$ & $62.00 \pm 1.154^{\mathrm{a}}$ \\
2nd group & 1 & $73.00 \pm 1.732^{\mathrm{b}}$ & $73.00 \pm 1.732^{\mathrm{b}}$ \\
3rd group & &
\end{tabular}

Means with different superscripts in the same column are significantly different at $\mathrm{P}<0.05$.

Chu, Y. and Dieter, R. R. (1989): Monocyte function in chickens with heredity dystrophy. Poult. Sci., 68: 226-232.

Ebert, E. C. (1989): Proliferative responses of human intraepithelial lymphocytes to various T-cell stimuli. Gastroenterol., 97: 1372-1381.

Ebert, E. C. (1990): Intra-epithelial lymphocytes: interferon-gamma production and suppressor/cytotoxic activities. Clin. Exp. Immunol., 82:81-5.

Fuller, R. (1989): Probiotics in man and animals (A review). J. Appl. Bacterol., 66: 365-378.

Galdeano, M. C.; Moreno de - LeBlanc, A - de; Vinderola, G.; Bibas - Bonet, M. E. and Perdigon, G. (2007): Proposed model: mechanisms of immunomodulation induced by probiotic bacteria. Clinical and Vaccina Immunol., 14(5): 485-492.

Gunal, M.; Yayli, G.; Kaya, O.; Karahan, N.; and Sulak, O. (2006): The effect of antibiotic growth promoter, probiotic or organic acid supplementation on performance, intestinal microflora and tissue of broiler. Int. J. Poult. Sci., 5: 149-155.

Hamid, R.; Jianhua, G.; Carlton, I.; Anthony, H.; H.uaijun, Z.; Babak, S.; James, R. and Shayan, S. (2006): Probiotic stimulate production of natural antibiotics in chickens. Clin. Vaccine Immunol., 13(9): 975-980.

Hanks, D. H. and Wallace, O. H. (1985): Determination of cell viability. Proc. Soc. Exp. Biol. Med., 98: 183-192.

Islam, M. W.; Rahman, M. M.; Kabir, S. M. L.; Kamruzzaman, S. M. and Islam, M. N. (2004): Effects of probiotics supplementation on growth performance and certain haemato - biochemical parameters in broiler chickens. Bangl. J. Vet. Med., 2(1): 39-43.

Isolauri, E.; Sutas, Y.; Kankaanpaa, P.; Arvilommi, H. and Salminen, S. (2001): Probiotic effects on immunity. Am. J. Clin. Nut., 73(2 supplement): 4445-4505.

Kabir, S. M. L.; Rahman, M. B.; Rahman, M. M. and
Ahmed, S. U. (2004): The dynamics of probiotics on growth performance and immune response in broilers. Int. J. Poult. Sc., 3: 361-364.

King, D. J. and Seal, B. S. (1998): Biological and molecular characterization of Newcastle disease virus (NDV) field isolates with comparisons to reference NDV strains and pathogenicity after chicken or embryo passage of selected isolates. Avian Dis., 42: 507-516.

Midilli, M.; Tuncer, S. D.; Bayram, I. and Kilinc, C. (2004): The effects of supplementation of enzyme and proboitic to the rations on some blood parameters of broiler. Ind. Vet. J., 81(11): 1213-1216.

Mohan, B.; Kadirevel, R.; Natarajan, A. and Bhaskaran, M. (1996): Effect of probiotic supplementation on growth, nitrogen utilization and serum cholesterol in broilers. Br. Poult. Sci., 37: 395-401.

National Research Council (1994): Nutrient Requriements of poultry. th $^{\text {th }}$ Edn,National Academy press, Washington,DC.,USA,ISBN-10:0-309-04892-3.

Nayebpor, M.; Farhomand, P. and Hashemi, A. (2007): Effect of different levels of direct fed microbial (primalac) on the growth performance and humoral immune response in broiler chickens. J. Anim. Adv., 6: 1308-1313.

Pelicano, E. R. L.; Souza, P. A. de.; Souza, H. B. A. de.; Oba, A.; Norkus, E. A.; Kodawara, L. M. and Lima, T. M. A. de. (2003): Effect of different probiotics on broiler carcass and meat quality. Braz. J. Poult. Sci., 5 (3): 207214.

Petrie, A. and Watson, P. (1999): Statics for Veterinary and Animal Science $1^{\text {st }}$ Ed. The black well. Science L. td, United Kingdom pp. 90-99.

Rangasamy, M. and Kaliappan, K. (2007): Panchagavya and Andrographis paniculata as alternatives to antibiotic growth promoters on haematological, serum biochemical parameters and immune status of broilers. J. Poult. Sci., 44: 198-264. 
Reid, G.; Jass, J.; Sebulsky, M. T. and McCormick, J. K. (2003): Potential uses of probiotics in clinical practice. Clin. Microbiol. Rev., 16: 658- 672.

Schiffrin, E. J.; Brassart, D.; Servin, L. A.; Rochat, F.and Donnet-Hughes, A. (1997): Immune modulation of blood leukocytes in humans by lactic acid bacteria: criteria for strain selection. Am. J. Clin. Nutr., 66: 515-520.

Snedecor, G. W. (1969): "Statistical methods" Fourth Ed.; The lowa state, college press, Ames lowa.

Swain, S. K.; Rangacharyulu, P. V.; Sarka, S. and Das, K. M. (1996): Effect of probiotic supplement on growth, nutrient utilization and carcass composition in mrigal Fry

Thitaram, S. N.; Chung, C. H.; Day, D. F.; Hinton, A.; Bailey, J. S. and Siragusa, G. R. (2005): Isomaltooligosaccharide increases cecal Bifidobacterium population in young broiler chickens. Poult. Sci., 84: 9981003.

Tietz, N. W. (1995): Clinical Guide to Laboratory Test, $3^{\text {rd }}$ Ed.; p. 102- 104 and 486-487.

Tietz, N. W. (1999): Text book of clinical chemistry $3^{\text {rd }}$ Ed. C. A. Burtis, E. R. Ashwood, W. B. Saunders; p.: 652-657.

Vinderola, G.; Perdigon, G.; Duarte, J.; Farnworth, E. and Matar, C. (2006): Effects of the oral administration of the exopolysaccharide produced by Lactobacillus kefiranofaciens on the gut mucosal immunity. Cytokine, 36 (516): 254-260.

Willis, W. L.; Isikhuemhen, O. S. and Ibrahim, A. (2007): Performance assessment of broiler chickens given mushroom extract alone or in combination with proboitics. Poult. Sci., 86: 1856-1860.

Wray, C. and Davies, R. H. (2000): Competitive exclusion an alternative to antibiotics. Vet. J., 159: 107-108.

Wysocka, M. (2001): Probiotics - new, hopeful uses in therapy. Nowa Pediatria, 5(26):19-24.

Yalcinkayal, H.; Gungori, T.; Bafialani, M. and Erdem, E. (2008): Mannan oligosaccbarides (MOS) from saccharomyces cerevisiae in broilers: Effects on performance and blood biochemistry. Turk. J. Vet. Anim. Sci., 32: 43-48.

Young, D. S. (1995): Effect of Drugs on Clinical Laboratory Tests, $4^{\text {th }}$ Ed. P. 3- 16 to 3-22.

Zulkifli, I.; Abdullah, N.; Azrin, N. M. and Ho, Y. W. (2000): Growth performance and immune response of two commercial broiler strains fed diets containing lactobacillus cultures and oxytetracycline under heat stress conditions. Br. Poult. Sci., 41: 593-597.

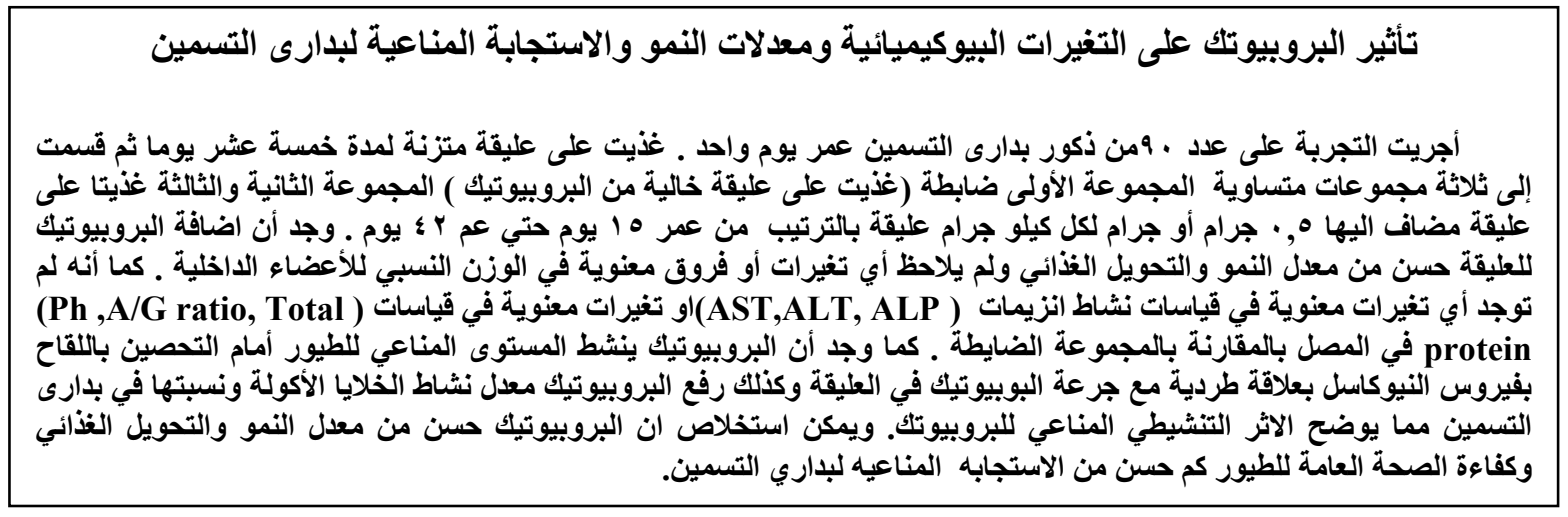

